\title{
Lessons for Primary Care from the First Ten Years of Medicare Coordinated Care Demonstration Projects
}

\author{
Winston Liaw, MD, MPH, Miranda Moore, PhD, Chimaraoke Iko, BA, and \\ Andrew Bazemore, $M D, M P H$
}

Over the past decade, Medicare has tested care coordination programs in an effort to achieve the triple aim of improving the patient experience, improving population health, and lowering costs. Although savings from this promising concept have not materialized, private payers are starting to offer blended payments to primary care. From these demonstrations, we propose 5 lessons for practices implementing care coordination: (1) minimize expenses by sharing resources and avoiding cost ineffective interventions; (2) concentrate on high utilizers; (3) foster relationships with both providers and patients; (4) track patients across the medical neighborhood in real time; and (5) extend rather than a duplicate the efforts of primary care practices. (J Am Board Fam Med 2015;28:556-564.)

Keywords: Case Management, Health Policy, Medicare, Primary Health Care

In their 1999 landmark article, Bodenheimer et $\mathrm{al}^{1}$ famously declared that primary care providers (PCPs) should be coordinators, not gatekeepers. While unfettered access to specialists is costly, they concluded that the gatekeeping model is too rigid. They envisioned a system in which PCPs facilitate, rather than impede, access and receive payments to coordinate care. Fifteen years later, complex patients still experience fragmented care, ${ }^{2}$ and payments for care coordination are just now entering the mainstream.

Initiatives to better coordinate care grew out of concerns surrounding the rise of chronic conditions. $^{3-5}$ This ecological shift has escalated complexity for $\mathrm{PCPs},{ }^{6}$ and as the US population con-

This article was externally peer reviewed.

Submitted 17 November 2014; revised 25 April 2015; accepted 29 April 2015.

From the Department of Family Medicine, Virginia Commonwealth University, Fairfax Family Medicine Residency Program, Fairfax (WL); and the Robert Graham Center, Policy Studies in Family Medicine and Primary Care, Washington, DC (MM, CI, AB).

Funding: Funding for this work was provided by the American Academy of Family Physicians.

Conflict of interest: none declared.

Corresponding author: Winston Liaw, MD, MPH, 3650 Joseph Siewick Dr., \#400, Fairfax, VA 22033 (E-mail: wliaw@ffpcs.com). tinues to age, these trends are only expected to become more pronounced.

The Agency for Health care Research and Quality defines care coordination as the "deliberate organization of patient care activities between 2 or more participants (including the patient) involved in a patient's care to facilitate the appropriate delivery of health care services."7 Today, these programs hold great promise in helping to achieve the triple aim of improving the individual experience, improving the health of populations, and reducing the costs of care. ${ }^{8}$

New models of payment that encourage care coordination, such as the recently passed Medicare alternative payment model, reward improvements in quality and reductions in costs. ${ }^{9}$ Previously, payments for care coordination were available only to demonstration project participants and large health systems. Some payers are beginning to offer these payments to smaller practices, and Medicare now offers a chronic care management code to reimburse care coordination activities. ${ }^{10}$ Four Centers for Medicare \& Medicaid Services (CMS) demonstration projects involved care management fees: (1) Medicare Coordinated Care Demonstration (MCCD), (2) Care Management for High-Cost Beneficiaries (CMHCB), (3) Multi-Payer Advanced 
Primary Care Practice (MAPCP), and (4) Comprehensive Primary Care Initiative (CPCI). These provide historic context to the current market, elucidate those services that have been tried in the past, and provide insights into where care coordination is headed. ${ }^{11-26}$ (Note that the terms care management, care coordination, and case management are related, albeit distinct concepts. We included demonstration projects that offered care management fees [the term used in solicitations in the Federal Register]. The individual programs used different terms to describe personnel, including care coordinators, care managers, and case managers.)

\section{Lessons for Primary Care}

We reviewed the available evaluations for CMS demonstrations and categorized the services provided (Table 1). Early evaluations suggest that these payments have limited returns on investment (Table 2), but before prematurely abandoning care coordination, we offer 5 lessons from the past 10 years of demonstrations. While these hypotheses require further investigation, these characteristics and tactics were common among successful programs.

\section{Minimize Expenses by Sharing Resources and Avoiding Cost-ineffective Interventions}

High-cost interventions such as paying for medications and reimbursing providers for reviewing care plans failed to generate savings. ${ }^{27,28,33}$ Subsequently, care management fees plummeted (Figure 1) as CMS shifted from specific diseases (MCCD, CMHCB) to entire practice populations (MAPCP, CPCI). This reduction reflects the disappointing results of early demonstrations; only 2 MCCD programs were able to generate enough savings to offset the care management fees.

The impact of other expensive interventions such as telemonitoring was mixed. Seven of the MCCD and 5 of the CMHCB programs incorporated telemonitoring devices, though utilization varied. For example, $1.3 \%$ of Mercy's MCCD cohort was given home monitoring devices compared with $100 \%$ of the cohort from the University of Maryland. ${ }^{33}$ In response to concerning vital signs, coordinators from CMHCB's Health Buddy Program adjusted follow-up intervals, ultimately reducing mortality and hospitalizations. ${ }^{51}$ By contrast, improvements were not seen in MCCD's Avera program, which dis- tributed monitoring devices to $83 \%$ of its population. $^{51}$ These devices were absent from MAPCP proposals.

Sharing care coordination resources can also minimize costs. Under Vermont's Blueprint for Health, care coordinators working in community health teams are split among multiple practices. This arrangement allows smaller practices to implement services they otherwise would be unable to afford. ${ }^{52}$ Within MAPCP, 5 states offer payments for community health teams.

\section{Concentrate on High Utilizers}

To generate savings, resource allocation cannot be homogenous. Instead, practices must focus more intensely on those at highest risk for utilization.

Of the eleven MCCD programs that continued for 2 additional years (2006 to 2008), 2 reduced hospitalizations. That figure doubled when researchers looked at just high utilizers. ${ }^{53}$

Despite the importance of identifying high utilizers, the process of risk stratification varied widely. Of the 21 programs in MCCD and CM$\mathrm{HCB}, 11$ assigned patients into stratified risk levels. Three of those used risk calculators, whereas the remaining programs relied on subjective impressions of risk.

Following MCCD, CMS used alternative payment models to more directly incentivize cost reduction. Specifically, CMS instituted a fee-at-risk model for CMHCB and shared savings for MAPCP and CPCI. When programs had incentives to generate savings, they allocated resources to support high-cost populations. For instance, under CMHCB, 4 programs provided mental health treatment resources and all included end-of-life interventions.

\section{Foster Relationships with Both Providers and Patients}

Similar to providers who must build relationships with patients, ${ }^{54}$ care coordinators must engender trust with both patients and providers. Only 4 of the 15 MCCD programs met recruitment goals during the first years, and programs with close ties to physician groups were more likely to meet those goals. $^{12}$

The Washington University MCCD Program provided another case study in the importance of face-to-face interactions. ${ }^{55}$ Initially, the program increased total Medicare spending by $12 \%$, but after a redesign, care coordination moved from a 


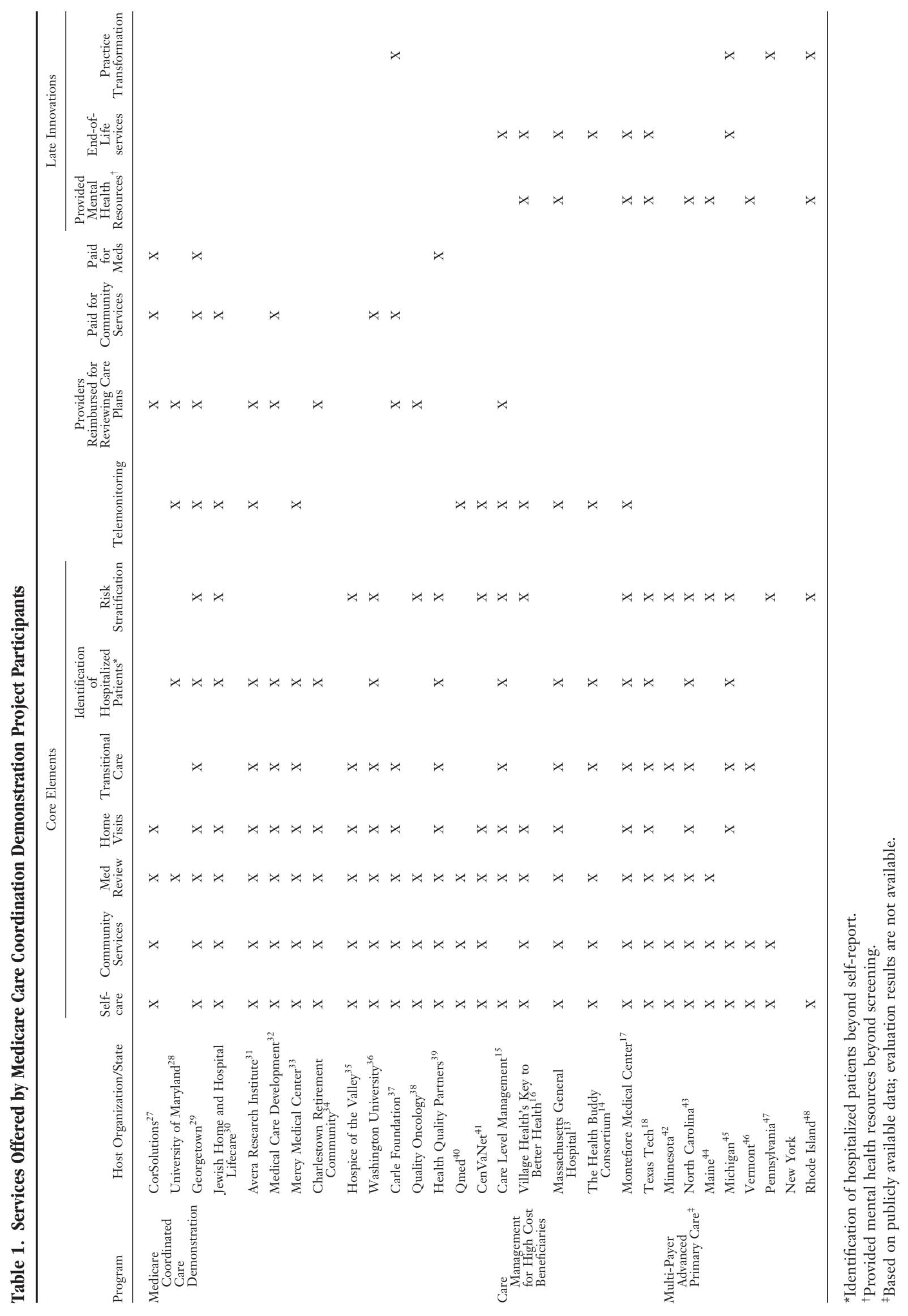

c

$\stackrel{N}{N}$

产

กิ

o

$\vec{A}$ 
Table 2. Characteristics of Medicare Demonstration Projects That Focus on Care Coordination

\begin{tabular}{|c|c|c|c|c|}
\hline & $\begin{array}{l}\text { Medicare Coordinated } \\
\text { Care Demonstration }\end{array}$ & $\begin{array}{l}\text { Care Management for High- } \\
\text { Cost Beneficiaries } \\
\text { Demonstration }\end{array}$ & $\begin{array}{l}\text { Multi-Payer Advanced } \\
\text { Primary Care Practice } \\
\text { Demonstration }\end{array}$ & $\begin{array}{l}\text { Comprehensive Primary } \\
\text { Care Initiative }\end{array}$ \\
\hline Start year & 2002 & 2005 & 2011 & 2012 \\
\hline Duration (years) & & 3 & 3 & 4 \\
\hline Patients involved (n) & $\sim 16,000$ & $\sim 28,000$ & $\sim 900,000$ & $\sim 313,000$ \\
\hline $\begin{array}{l}\text { Programs/states } \\
\text { involved }\end{array}$ & 15 Programs & 6 Programs & 8 States & 7 Markets in 8 states \\
\hline Payer(s) involved & Medicare & Medicare & $\begin{array}{l}\text { Medicare, Medicaid, } \\
\text { private health plans }\end{array}$ & $\begin{array}{l}\text { Medicare, Medicaid, private } \\
\text { health plans }\end{array}$ \\
\hline Program goal(s) & $\begin{array}{l}\text { Determine whether case } \\
\text { management and } \\
\text { disease management } \\
\text { programs can lower } \\
\text { costs and improve } \\
\text { patient outcomes }\end{array}$ & $\begin{array}{l}\text { Determine whether pay-for- } \\
\text { performance and new } \\
\text { strategies for complex, } \\
\text { high-cost patients, reduce } \\
\text { costs, improve quality, and } \\
\text { improve beneficiary and } \\
\text { provider satisfaction }\end{array}$ & $\begin{array}{l}\text { Assess the effect of } \\
\text { advanced primary } \\
\text { care practice (ie, the } \\
\text { patient-centered } \\
\text { medical home) on } \\
\text { health care } \\
\text { effectiveness, } \\
\text { quality, patient } \\
\text { engagement, and } \\
\text { cost }\end{array}$ & $\begin{array}{l}\text { Test whether comprehensive } \\
\text { primary care, coupled } \\
\text { with payment reform, use } \\
\text { of data to guide } \\
\text { improvement, and } \\
\text { meaningful use of health } \\
\text { information technology, } \\
\text { can achieve the 3-part aim } \\
\text { of better care, improved } \\
\text { health, and reduced costs }\end{array}$ \\
\hline $\begin{array}{l}\text { Who designed the } \\
\text { intervention? }\end{array}$ & Programs & Programs & States & $\begin{array}{l}\text { Centers for Medicare and } \\
\text { Medicaid Services }\end{array}$ \\
\hline Evaluation & & & & \\
\hline Design & $\begin{array}{l}\text { Patients were } \\
\text { randomized and } \\
\text { controlled }\end{array}$ & $\begin{array}{l}\text { Patients were randomized and } \\
\text { controlled }\end{array}$ & Evaluation is ongoing & Evaluation is ongoing \\
\hline Expenses & $\begin{array}{l}\text { Three (Health Quality } \\
\text { Partners, } \\
\text { Georgetown, and } \\
\text { Mercy) cost less than } \\
\text { controls } \\
\text { Two (Health Quality } \\
\text { Partners and } \\
\text { Georgetown) had } \\
\text { savings enough to } \\
\text { offset fees. }\end{array}$ & $\begin{array}{l}\text { One (Massachusetts General } \\
\text { Hospital) achieved cost } \\
\text { savings } s^{13}\end{array}$ & Evaluation is ongoing & \\
\hline $\begin{array}{l}\text { Hospitalizations/ } \\
\text { mortality }\end{array}$ & $\begin{array}{l}\text { One (Mercy) had fewer } \\
\text { hospitalizations than } \\
\text { controls }\end{array}$ & $\begin{array}{l}\text { Three (Health Buddy } \\
\text { Consortium, Massachusetts } \\
\text { General Hospital, and } \\
\text { CareLevel Management) } \\
\text { had lower all-cause } \\
\text { hospitalization rates }{ }^{13-15} \\
\text { Two (Massachusetts } \\
\text { General Hospital and the } \\
\text { Health Buddy Consortium) } \\
\text { achieved mortality } \\
\text { reductions. }\end{array}$ & & \\
\hline $\begin{array}{l}\text { Payment structure on } \\
\text { top of fee-for- } \\
\text { service }\end{array}$ & $\begin{array}{l}\text { Per-enrollee, per-month } \\
\text { payments only }\end{array}$ & $\begin{array}{l}\text { Monthly payments were held } \\
\text { at risk based on } \\
\text { performance. There was } \\
\text { also a shared savings } \\
\text { provision. }\end{array}$ & $\begin{array}{l}\text { Per-beneficiary, per- } \\
\text { month payment } \\
\text { (dependent on } \\
\text { patient complexity } \\
\text { and the medical } \\
\text { home level achieved } \\
\text { by the practice) } \\
\text { Community health } \\
\text { teams also receive } \\
\text { payments. }\end{array}$ & $\begin{array}{l}\text { Shared savings (in years } 3 \\
\text { and } 4 \text { ) in addition to per- } \\
\text { beneficiary, per-month } \\
\text { payments }\end{array}$ \\
\hline $\begin{array}{l}\text { Shared savings } \\
\text { component }\end{array}$ & No & Yes & Yes ( 1 of the 8 states) & Yes \\
\hline $\begin{array}{l}\text { Community health } \\
\text { teams }\end{array}$ & No & No & Yes (5 of the 8 states) & No \\
\hline $\begin{array}{l}\text { Per-enrollee, per- } \\
\text { month range }(\$)\end{array}$ & $50-437$ & $117-295$ & $\begin{array}{l}0.60-58.50 \text { (for care } \\
\text { management fees) } \\
1.16-6.50 \text { (for } \\
\text { community health } \\
\text { teams) }\end{array}$ & $8-40$ \\
\hline
\end{tabular}

remote site in California to local care coordinators in St. Louis. In addition to stronger transitional care, this change allowed coordinators to conduct more in-person encounters and resulted in a $12 \%$ reduction in hospitalization and, ultimately, savings that more than offset the care management fee. ${ }^{55}$ The Massachusetts General Hospital (MGH) program reduced mortality and expenses and expected 
Figure 1. Average monthly per-member payments for Medicare demonstration programs. 1. We averaged the monthly care management fees per host organization. The fees were obtained from Brown et al. ${ }^{12}$. We averaged the monthly care management fee for each organization across the demonstration's 3 years and then averaged the fees across the 6 organizations. We obtained the fee amounts from RTI International's evaluation of each organization. 3. The monthly care management fee schedule varied by state, with some states adjusting for the practice's medical home status and patient complexity. Five states allocated additional payments for community health teams. For this calculation, we averaged the maximum and minimum possible payments per state, added this amount to the community health team fee (when available), and then averaged the fees across the states. We obtained the monthly fees from Centers Medicare and Medicaid Services (CMS) data. ${ }^{50}$ 4. The CMS paid an average of $\$ 20$ per beneficiary per month (PBPM) for the first 2 years and then \$15 PBPM for the last 2 years. We averaged these 2 amounts across the 4 years. ${ }^{26} 5$. Only patients with program-defined, high-cost diagnoses were eligible to participate. 6. All Medicare beneficiaries within practices were eligible to participate.

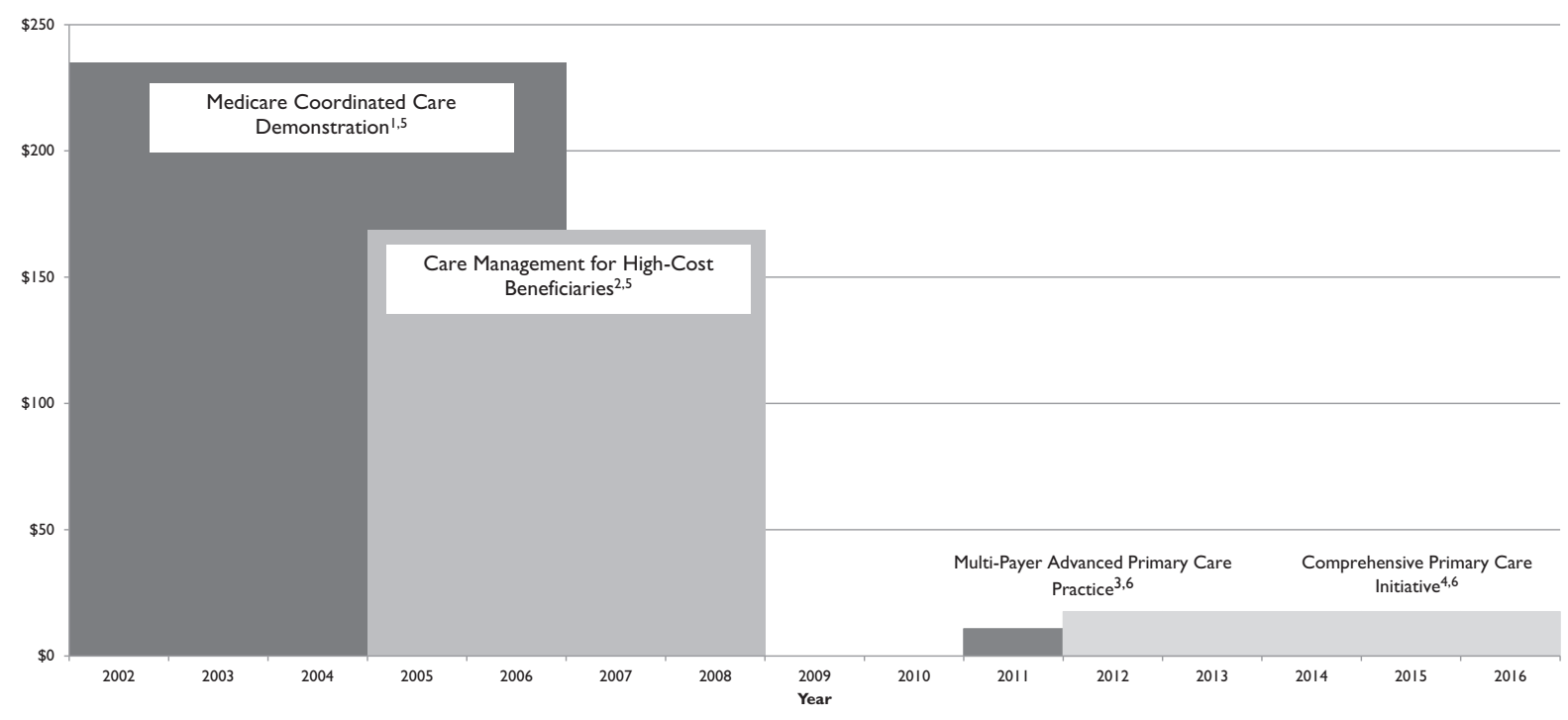

care managers to develop one-on-one relationships with both patients and primary care offices so that the care managers would be seen as part of the practice's staff. $^{13}$

Mercy's staff attributed reductions in hospitalizations to getting patients to see their physicians when symptoms worsened. By identifying problems early, the care coordinators intervened before patients' health deteriorated. ${ }^{12}$ Evaluators reported that Mercy had the highest proportion of in-person contacts. When caring for elderly, often hard-of-hearing Medicare beneficiaries, developing relationships over the phone can be difficult with a rotating cadre of care coordinators.

\section{Track Patients Across the Medical Neighborbood in Real Time}

Receiving claims data after a hospitalization does not allow a practice to respond during a crisis. MGH care managers followed patients across the continuum of care in real time, receiving pages for emergency department visits and E-mails for admissions. ${ }^{13}$
Transitional care among other programs varied widely. For instance, 6 MCCD programs lacked a systematic method for identifying patients that had been seen in emergency rooms or hospitalized and instead relied on patients or caregivers to inform them of the hospitalization afterward. Eight MCCD programs had protocols requiring coordinators to contact patients during or following hospitalizations. Of the MCCD and CMHCB programs, 9 were affiliated with a hospital or medical center (8 of which had systems to systematically identify hospitalized patients). The remaining programs lacked access to real-time information about urgent and emergent services use. Tools such as health information exchanges are important first steps in sharing data across medical neighborhoods.

\section{Extend Rather Than Duplicate the Efforts of Primary Care Practices}

Starfield et $\mathrm{al}^{56}$ described the essential features of primary care as (1) first-contact care, (2) ongoing person-focused care, (3) comprehensiveness, and 
(4) coordination of care. One might argue, however, that coordination is so inherent to the delivery of primary care that providing these services does not warrant additional payment.

If care coordination and primary care operate in silos, processes (such as checking on patients after hospitalizations) will be duplicated. If primary care practices and care coordinators fail to integrate, coordination from the patient perspective will become more complex, with patients receiving redundant and possibly conflicting advice.

Care coordinators at MGH shared an electronic medical record with their partnering providers, creating opportunities for enhanced communication. For example, MGH modified its electronic medical record to include an icon alerting providers that the patient was in the care management program. On the day the program launched, the MGH emergency department informed the care coordinators that dozens of their patients were in the emergency department. ${ }^{13}$ The care coordinators knew when patients had upcoming appointments and could plan to meet them face to face. By contrast, only 6 of the 15 MCCD programs had access to outpatient or inpatient records. ${ }^{12}$

\section{Conclusion}

Care coordination sits at the nexus of multiple health care ideals: the chronic care model, the triple aim, and the integration of public health and primary care. ${ }^{57}$ Generating savings requires investments on the care coordination infrastructure. Spending too much on the infrastructure means that an unrealistic amount of savings needs to be achieved to justify the initial investment. Spending too little will also fail to generate savings because practices may be unable or unwilling to make important, but costly, investments. The challenge for care coordination is in finding the amount of investment that will yield the optimal return.

\section{References}

1. Bodenheimer T, Lo B, Casalino L. Primary care physicians should be coordinators, not gatekeepers. JAMA 2009;281:2045-9.

2. Hempstead K, Delia D, Cantor JC, Nguyen T, Brenner J. The fragmentation of hospital use among a cohort of high utilizers: implications for emerging care coordination strategies for patients with multiple chronic conditions. Med Care 2014;52:S67-74.

3. Centers for Medicare and Medicaid Services. Chronic conditions among Medicare beneficiaries.
Baltimore (MD): Centers for Medicare and Medicaid Services; 2012. Available from: http://www.cms. gov/Research-Statistics-Data-and-Systems/StatisticsTrends-and-Reports/Chronic-Conditions/Downloads/ 2012Chartbook.pdf. Accessed April 24, 2015.

4. Centers for Medicare and Medicaid Services. Solicitation for proposals for the Medicare Coordinated Care Demonstration. Baltimore (MD): Centers for Medicare and Medicaid Services; 2000. Available from: http://www.cms.gov/Medicare/DemonstrationProjects/DemoProjectsEvalRpts/downloads/CC_ Solicitation_p.pdf. Accessed April 24, 2015.

5. National Center for Chronic Disease Prevention and Health Promotion. At a glance: 2015: National Center for Chronic Disease Prevention and Health Promotion; 2015. Available from: http://www.cdc.gov/ chronicdisease/resources/publications/aag/pdf/2015/ nccdphp-aag.pdf. Accessed July 28, 2015.

6. Pham HH, O'Malley AS, Bach PB, Saiontz-Martinez C, Schrag D. Primary care physicians' links to other physicians through Medicare patients: The scope of care coordination. Ann Intern Med 2009; 150:236-42.

7. McDonald KM, Sundaram V, Bravata DM, et al. Closing the quality gap: a critical analysis of quality improvement strategies (Vol. 7: care coordination). Rockville (MD): Agency for Healthcare Research and Quality; 2007. Available from http:// www.ncbi.nlm.nih.gov/books/NBK44015/pdf/ TOC.pdf. Accessed April 24, 2015.

8. Berwick DM, Nolan TW, Whittington J. The triple aim: care, health, and cost. Health Aff (Millwood) 2008;27:759-69.

9. H.R.2 - Medicare Access and CHIP Reauthorization Act of 2015. 2015. Available from: https://www. congress.gov/bill/114th-congress/house-bill/2/text. Accessed April 25, 2015.

10. Centers for Medicare \& Medicaid Services. Details for title: CMS-1612-P. Baltimore (MD): Centers for Medicare \& Medicaid Services; 2014. Available from http://www.cms.gov/Medicare/Medicare-Fee-forService-Payment/PhysicianFeeSched/PFS-FederalRegulation-Notices-Items/CMS-1612-P.html? DLPage $=1 \&$ DLSort $=2 \& D L S o r t D i r=$ descending. Accessed April 24, 2015.

11. Brown R, Peikes D, Chen A, Schore J. 15-site randomized trial of coordinated care in Medicare FFS. Health Care Financ Rev 2008;30:5-25.

12. Brown R, Peikes D, Chen A, Ng J, Schore J, Soh C. The evaluation of the Medicare Coordinated Care Demonstration: findings for the first two years. Princeton (NJ): Mathematica Policy Research; 2007. Available from: http://innovation.cms.gov/Files/x/ Evaluation-of-Medicare-Coordinated-Care.pdf. Accessed April 24, 2015.

13. McCall N, Cromwell J, Urato C. Evaluation of Medicare Care Management for High Cost Beneficiaries (CMHCB) Demonstration: Massachusetts 
General Hospital and Massachusetts General Physicians Organization (MGH). Final report. Research Triangle Park (NC): RTI International; 2010. Available from: http://www.cms.gov/Research-StatisticsData-and-Systems/Statistics-Trends-and-Reports/ Reports/downloads/mccall_mgh_cmhcb_final_2010. pdf. Accessed April 24, 2015.

14. McCall N, Cromwell J, Smith, K, Urato C. Evaluation of Medicare Care Management for High Cost Beneficiaries (CMHCB) Demonstration: The Health Buddy Consortium (HBC). Revised final report. Research Triangle Park (NC): RTI International; 2011. Available from: http://www.cms.gov/ Research-Statistics-Data-and-Systems/StatisticsTrends-and-Reports/Reports/downloads/McCall_ Eval_of_CMHCB_Demo_April_2011.pdf. Accessed April 24, 2015.

15. McCall N, Cromwell J, Urato C, Eng T. Evaluation of Medicare Care Management for High Cost Beneficiaries (CMHCB) Demonstration: Care Level Management (CLM). Final report. Research Triangle Park (NC): RTI International; 2010. Available from: http://www.cms.gov/ Research-Statistics-Data-and-Systems/Statistics-Trendsand-Reports/Reports/downloads/CMHCB_CLM_ McCall_2010.pdf. Accessed April 24, 2015.

16. McCall N, Cromwell J, Urato C. Evaluation of Medicare Care Management for High Cost Beneficiaries (CMHCB) Demonstration: VillageHealth's Key to Better Health $(\mathrm{KTBH})$. Final report. Research Triangle Park (NC): RTI International; 2010. Available from: https://www.cms.gov/ResearchStatistics-Data-and-Systems/Statistics-Trends-andReports/Reports/downloads/McCall_KTBH_Final_ 2010.pdf. Accessed April 24, 2015.

17. McCall N, Cromwell J, Urato C. Evaluation of Medicare Care Management for High Cost Beneficiaries (CMHCB) Demonstration: Montefiore Medical Center's Care Guidance Program (CGP). Revised final report. Research Triangle Park (NC): RTI International; 2011. Available from: http:// www.cms.gov/Research-Statistics-Data-and-Systems/ Statistics-Trends-and-Reports/Reports/downloads/ McCall_MontefioreFinalReport_May_2011.pdf. Accessed April 24, 2015.

18. McCall N, Cromwell J, Urato C, Eng T. Evaluation of Medicare Care Management for High Cost Beneficiaries (CMHCB) Demonstration: Texas Senior Trails (TST). Final report. Research Triangle Park (NC): RTI International; 2010. Available from: http://www.cms.gov/Research-Statistics-Data-andSystems/Statistics-Trends-and-Reports/Reports/ downloads/CMHCB_TST_McCall_2010.pdf. Accessed April 24, 2015.

19. Patient-Centered Primary Care Collaborative. Defining the medical home. Washington (DC): $\mathrm{Pa}-$ tient-Centered Primary Care Collaborative; 2013. Available from: http://www.pcpcc.org/about/medicalhome. Accessed April 24, 2015.
20. Patient Protection and Affordable Care Act of 2010, PL 111-148, sec. 3021.

21. Barr MS, Foote SM, Krakauer R, Mattingly PH. Lessons for the new CMS Innovation Center from the Medicare Health Support Program. Health Aff (Millwood) 2010;29:1305-9.

22. Buxbaum J, Takach M. State multi-payer medical home initiatives and Medicare's Advanced Primary Care Demonstration. Washington (DC): National Academy for State Health Policy; 2010. Available from http://www.nashp.org/sites/default/files/ MedHomesWebinar.pdf. Accessed April 24, 2015.

23. Centers for Medicare and Medicaid Services. Multipayer Advanced Primary Care Practice Demonstration. Questions \& answers-updated April 12, 2011. Baltimore (MD): Centers for Medicare and Medicaid Services; 2011. Available from: http://www.cms. gov/Medicare/Demonstration-Projects/Demo ProjectsEvalRpts/downloads/mapcpdemo_QA.pdf. Accessed April 24, 2015.

24. Friedberg MW, Schneider EC, Rosenthal MB, Volpp KG, Werner RW. Association between participation in a multipayer medical home intervention and changes in quality, utilization, and costs of care. JAMA 2014;311:815-25.

25. Center for Medicare and Medicaid Intervention. Comprehensive Primary Care (CPC) Initiative: primary care practice solicitation. Baltimore (MD): Centers for Medicare and Medicaid Services; 2011. Available from: http://innovation.cms.gov/Files/x/ CPC_PracticeSolicitation.pdf. Accessed April 24, 2015.

26. Centers for Medicare and Medicaid Services. FAQ: the CPC initiative and participation in other CMS initiatives. Baltimore (MD): Centers for Medicare and Medicaid Services; 2012. Available from: http:// innovation.cms.gov/Files/x/Comprehensive-PrimaryCare-Initiative-Frequently-Asked-Questions.pdf. Accessed April 24, 2015.

27. Sautter K, Schore J, Brown R, Aliotta S, Peikes D, Orzol S. The CorSolutions Medicare Coordinated Care Demonstration Program after one year. Final report. Princeton (NJ): Mathematica Policy Research; 2005. Available from: http://www.mathematica-mpr. $\mathrm{com} / \sim / \mathrm{media} /$ publications/pdfs/corsolutionsoneyear. pdf. Accessed April 24, 2015.

28. Archibald N, Schore J, Brown R, Peikes D, Orzol S. The University of Maryland Medicare Coordinated Care Demonstration Program after one year. Princeton (NJ): Mathematica Policy Research; 2005. Available from: http://www.mathematica-mpr.com/ publications/PDFs/universityofMD.pdf. Accessed April 24, 2015.

29. Sautter K, Schore J, Brown R, Chen A, Peikes D, Orzol S. The Georgetown Medicare Coordinated Care Demonstration Program after one year. Final report. Princeton (NJ): Mathematica Policy Research; 2004. Available from: http://www.mathematica-mpr. 
com/ /media/publications/PDFs/georgetownoneyear. pdf. Accessed April 24, 2015.

30. Archibald N, Schore J, Brown R, Peikes D, Orzol S. The Jewish Home and Hospital Lifecare System Medicare Coordinated Care Demonstration Program after one year. Final report. Princeton (NJ): Mathematica Policy Research; 2005. Available from: http://www. mathematica-mpr.com/ /media/publications/PDFs/ jewishhomeoneyear.pdf. Accessed April 24, 2015.

31. Sautter K, Schore J, Brown R, Aliotta S, Peikes D, Orzol S. The Avera Medicare Coordinated Care Demonstration Program after one year. Princeton (NJ): Mathematica Policy Research; 2005. Available from: http://www.mathematica-mpr.com/publications/PDFs/averaoneyear.pdf. Accessed April 24, 2015.

32. Chen A, Sautter K, Schore J, Brown R, Peikes D, Orzol S. The Medical Care Development Medicare Coordinated Care Demonstration Program after one year. Final report. Princeton (NJ): Mathematica Policy Research; 2005. Available from: http:// www.mathematica-mpr.com/ /media/publications/ pdfs/medicalcare.pdf. Accessed April 24, 2015.

33. Sautter K, Schore J, Brown R, Aliotta S, Peikes D, Orzol S. The Mercy Medicare Coordinated Care Demonstration Program after one year. Final report. Princeton (NJ): Mathematica Policy Research; 2004. Available from: http://www.mathematica-mpr.com/ publications/PDFs/mercyoneyear.pdf. Accessed April 24, 2015.

34. Archibald N, Schore J, Brown R, Peikes D, Orzol S. The Charlestown Retirement Community Medicare Coordinated Care Demonstration Program after one year. Final report. Princeton (NJ): Mathematica Policy Research; 2005. Available from: http:// www.mathematica-mpr.com/ /media/publications/ pdfs/charlestown.pdf. Accessed April 24, 2015.

35. Archibald N, Schore J, Brown R, Peikes D, Orzol S. The Hospice of the Valley's Medicare Coordinated Care Demonstration Program after one year. Final report. Princeton (NJ): Mathematica Policy Research; 2005. Available from: http://www.mathematica-mpr. com/ /media/publications/PDFs/hospiceoneyear.pdf. Accessed April 24, 2015.

36. Archibald N, Schore J, Brown R, Peikes D, Orzol S. The Washington University Medicare Coordinated Care Demonstration Program after one year. Final report. Princeton (NJ): Mathematica Policy Research; 2005. Available from: http://www. mathematica-mpr.com/ /media/publications/PDFs/ washingtonunivoneyear.pdf. Accessed April 24, 2015.

37. Schore J, Brown R, Peikes D, Orzol S. The Carle Medicare Coordinated Care Demonstration Program after one year. Princeton (NJ): Mathematica Policy Research; 2005. Available from: https:// cire.mathematica-mpr.com/ /media/publications/ pdfs/carle.pdf. Accessed April 24, 2015.

38. Chen A, Schore J, Brown R, Peikes D, Orzol S, Soh
C, Sautter K. The Quality Oncology Medicare Coordinated Care Demonstration Program after one year. Final report. Princeton (NJ): Mathematica Policy Research; 2005. Available from: http://www. mathematica-mpr.com/ /media/publications/pdfs/ qualityoncology.pdf. Accessed April 24, 2015.

39. Archibald N, Schore J, Brown R, Peikes D, Orzol S. The Health Quality Partners Medicare Coordinated Care Demonstration Program after one year. Final report. Princeton (NJ): Mathematica Policy Research; 2005. Available from: http://www. mathematica-mpr.com/ /media/publications/PDFs/ healthqualitypartners.pdf. Accessed April 24, 2015.

40. Sautter K, Schore J, Brown R, Aliotta S, Peikes D, Orzol S. The Qmed Medicare Coordinated Care Demonstration Program after one year. Final report. Princeton (NJ): Mathematica Policy Research; 2005. Available from: http://www.mathematica-mpr.com/ \% /media/publications/pdfs/qmedoneyear.pdf. Accessed April 24, 2015.

41. Archibald N, Schore J, Brown R, Peikes D, Orzol S. The CenVaNet Medicare Coordinated Care Demonstration Program after one year. Final report. Princeton (NJ): Mathematica Policy Research; 2005. Available from: http://www.mathematica-mpr.com/ / /media/publications/pdfs/cenvanet.pdf. Accessed April 24, 2015.

42. Multi-payer Advanced Primary Care Practice Demonstration Application. Minneapolis: Minnesota Department of Health, Minnesota Department of Human Services; 2010. Available from: http:// www.health.state.mn.us/healthreform/homes/medicare/ MN_MAPCPApplication.pdf. Accessed April 24, 2015.

43. Cosway R, Girod C, Abbott B. Analysis of Community Care of North Carolina cost savings. San Diego (CA): Milliman, Inc.; 2011. Available from: http://www.ncqa.org/Portals/0/Public\%20Policy/NC_millimanexecutive-summary_8.30.12.pdf. Accessed April 24, 2015.

44. Maine patient centered medical home pilot memorandum of agreement for participation. Maine PCMH pilot expansion \& MAPCP demonstration. Addendum. Available from: http://www.mainequalitycounts.org/image_ upload/PCMH\%20Pilot\%20Practice\%20Memorandum $\% 20$ of $\% 20$ Agreement $\% 20$ Addendum $\% 202012$.pdf. Accessed April 24, 2015.

45. Michigan primary care transformation project. Michigan Department of Community Health: 2011. Available from http://the-carebridge.com/sites/ default/files/pdfs/MiPCT-Summary.pdf. Accessed July 29, 2015.

46. Vermont Blueprint for Health implementation manual. Williston (VT): Department of Vermont Health Access; 2010. Available from http://blueprintforhealth. vermont.gov/sites/blueprint/files/BlueprintPDF/ printforhealthimplementationmanual2010-11-17.pdf. Accessed April 24, 2015.

47. Gabbay RA, Bailit MH, Mauger DT, Wagner EH, 
Siminerio L. Multipayer patient-centered medical home implementation guided by the chronic care model. Jt Comm J Qual Patient Saf 2011;37:265-73.

48. CSI-RI: strategic planning. Final plan. PCMH RhodeIsland.2013.Availablefromhttp://www.pcmhri. org/files/uploads/CSI_Strategic_Plan_Summary\%20 March\%202013.pdf. Accessed April 24, 2015.

49. Peikes D, Chen A, Schore J, Brown R. Effects of care coordination on hospitalization, quality of care, and health care expenditures among Medicare beneficiaries. JAMA. 2009;301:603-18.

50. Implementation support and payment processing for the Multi-payer Advanced Primary Care Practice Demonstration. Baltimore (MD): Centers for Medicare and Medicaid Services; 2011. Available from: http://www.cms.gov/Regulations-and-Guidance/ Guidance/Transmittals/downloads/R81DEMO.pdf. Accessed April 25, 2015.

51. Baker LC, Macaulay DS, Sorg RA, Diener MD, Johnson SJ, Birnbaum. Effects of care management and telehealth: a longitudinal analysis using Medicare data. J Am Geriatr Soc 2013;61:1560-7.

52. Bielaszka-DuVernay C. Vermont's Blueprint for medical homes, community health teams, and better health at lower cost. Health Aff (Millwood) 2011;30: 383-6.

53. Brown RS, Peikes D, Peterson G, Schore J, Razafindrakoto CM. Six features of Medicare Coordinated Care Demonstration Programs that cut hospital admissions of high-risk patients. Health Aff (Millwood) 2012;31:1156-66.

54. Tai-Seale M, McGuire TG, Zhang W. Time allocation in primary care office visits. Health Serv Res 2007;42:1871-94.

55. Peikes D, Peterson G, Brown RS, Graff S, Lynch JP. How changes in Washington University's Medicare Coordinated Care Demonstration pilot ultimately achieved savings. Health Aff (Millwood) 2012;31: 1216-26.

56. Starfield B, Shi L, Macinko J. Contributions of primary care to health systems and health. Milbank Q 2005;83:457-502.

57. Institute of Medicine. Integrating primary care and public health. Washington (DC): National Academies Press; 2012. 